\title{
Amplification of Epstein-Barr Virus (EBV) DNA by Superinfection with a Strain of EBV Derived from Nasopharyngeal Carcinoma
}

\author{
HIROSHI SATO,,$^{1,2}$ JOSEPH S. PAGANO, ${ }^{2}$ AND NANCY RAAB-TRAUB ${ }^{2 *}$ \\ Department of Virology, Cancer Research Institute, Kanazawa University, 13-1 Takaramachi, 920 Kanazawa, Japan, ${ }^{1}$ \\ and Department of Microbiology and Immunology and the Lineberger Cancer Research Center, School of Medicine, \\ University of North Carolina at Chapel Hill, Chapel Hill, North Carolina 27514
}

Received 25 January 1988/Accepted 28 May 1988

\begin{abstract}
Epstein-Barr virus (EBV) from a nasopharyngeal carcinoma (NPC) hybrid cell line (NPC-KT) lacking defective viral DNA molecules superinfected Raji cells and induced EBV early antigens (EA), as did virus from P3HR-1 cells, which contained defective molecules. The EBV polypeptides induced by NPC-KT appeared to be identical to those induced by P3HR-1 virus. The ability of NPC-KT virus to induce EA was enhanced more than 10-fold by treatment of superinfected cells with dimethyl sulfoxide; however, dimethyl sulfoxide treatment did not enhance superinfection by P3HR-1 virus. After infection, DNA synthesis of both the superinfecting NPC-KT virus and the resident Raji viral genome was induced. In addition to amplified Raji EBV episomal DNA, a fused terminal fragment of NPC-KT viral DNA was detected. The detection of fused terminal DNA fragments suggests that the superinfecting virion DNA either circularizes or polymerizes after superinfection and is possibly amplified through circular or concatenated replicative intermediates.
\end{abstract}

An Epstein-Barr virus (EBV)-carrying hybrid epithelial nasopharyngeal carcinoma (NPC) cell line (NPC-KT) was established by fusing primary NPC epithelial cells with an epithelial cell line derived from human adenoid tissue (28). This cell line produced virus with both transforming and efficient early antigen (EA)-inducing properties $(23,29)$. The HR-1 strain of EBV can induce EA relatively efficiently and is unable to immortalize lymphocytes $(8,15)$. The inability of HR-1 to immortalize lymphocytes has been mapped to a deletion of approximately 6,800 base pairs in the BamHI Y and $H$ fragments $(1,6,9,10,16,18,19)$. The DNA of HR-1 EBV has been characterized by partial denaturation mapping and restriction enzyme analysis $(1,2,4,7)$. These studies revealed a heterogeneity of HR-1 virus DNA with a subpopulation of defective molecules which contained specific EBV DNA sequences in an unusual linkage. The defective heterogeneous DNA molecules appear to promote the ability of the HR-1 strain to induce EA synthesis efficiently as well as viral DNA replication $(3,14,20)$. Superinfection with other strains of EBV which lack defective fragments at high multiplicities of infection can also induce EA synthesis but not viral DNA synthesis (12). The NPC-KT strain of EBV appears to be unique in that it has both transforming and efficient EA-inducing properties.

In the course of this study we determined that EA induction by NPC-KT, but not by HR-1, virus can be enhanced more than 10 times by treatment with dimethyl sulfoxide (DMSO). Although the mechanism of DMSO enhancement is unknown, it made it possible to analyze the superinfection process by the NPC-KT virus. The DNA of NPC-KT EBV was cloned into a cosmid vector, and its restriction enzyme map, when compared with that of B95-8 EBV DNA, revealed a lack of defective heterogeneous DNA molecules (T. Takimoto, M. Hatano, N. Raab-Traub, and J. S. Pagano, submitted for publication). In this study the superinfection process in Raji cells by NPC-KT EBV was further characterized by showing that the EBV polypeptides induced by NPC-KT virus are identical to those induced by the HR-1

\footnotetext{
* Corresponding author.
}

strain of EBV and that both the superinfecting NPC-KT virus and the resident Raji EBV genome are amplified, possibly through circular or concatenated replicative intermediates.

\section{MATERIALS AND METHODS}

Cell lines and virus strains. An epithelial-NPC hybrid cell line (NPC-KT) was maintained at $37^{\circ} \mathrm{C}$ as described previously (27). Virus was isolated from the supernatant fluids of NPC-KT cells that were pretreated with $60 \mu \mathrm{g}$ of 5-iodo- $2^{\prime}-$ deoxyuridine per $\mathrm{ml}$ at $34^{\circ} \mathrm{C}$. The fluids were passed through 0.8- $\mu \mathrm{m}$-pore-size filters (type AA; Millipore Corp., Bedford, Mass.) and virus was concentrated by centrifugation at 28,000 rpm for $90 \mathrm{~min}$ in a rotor (type 30; Beckman Instruments, Inc., Fullerton, Calif.) and suspended in a small volume of medium in order to achieve $100 \times$ concentrations. The lymphoblastoid cell line, P3HR-1, was maintained in RPMI 1640 medium supplemented with $10 \%$ fetal bovine serum. Extracellular virus was concentrated from P3HR-1 cultures as described above after induction with $20 \mathrm{ng}$ of 12-o-tetradecanoylphorbol-13-acetate (Sigma Chemical Co., St. Louis, Mo.) per ml.

Immunofluorescence. Raji cells $\left(2 \times 10^{5}\right)$ were infected with $0.1 \mathrm{ml}$ of concentrated or unconcentrated NPC-KT virus or $\mathrm{HR}-1$ virus and incubated at $37^{\circ} \mathrm{C}$ for $2 \mathrm{~h}$. The cells were then washed with medium and suspended in culture medium to a concentration of $2 \times 10^{5}$ cells per ml. DMSO (Sigma) was included in the culture medium at a final concentration of $1 \%(\mathrm{vol} / \mathrm{vol})$ or was omitted. After $48 \mathrm{~h}$ of incubation, cell smears were prepared on multitest slides and fixed in acetone. The cells were assayed for EBV EA by indirect immunofluorescence tests by using serum from patients with NPC (EA antibody titer, 1:160; viral capsid antigen (VCA), 1:640) and fluorescein isothiocyanate-conjugated goat anti-human immunoglobulin $\mathbf{G}$ serum.

Immunoprecipitation. Raji cells $\left(5 \times 10^{5}\right)$ were infected with NPC-KT or HR-1 and incubated in the presence or absence of DMSO for $12 \mathrm{~h}$, and were then labeled with $\left[{ }^{35} \mathrm{~S}\right]$ methionine $(40 \mu \mathrm{Ci} / \mathrm{ml})$ for $10 \mathrm{~h}$. Cells were pelleted and washed with cold phosphate-buffered saline solution. After 
TABLE 1. Effect of DMSO on EA induction by superinfection of Raji cells with NPC-KT and P3HR-1 viruses

\begin{tabular}{ccccc}
\hline \multirow{2}{*}{$\begin{array}{c}\text { Virus } \\
\text { preparation }\end{array}$} & DMSO & \multicolumn{3}{c}{ \% EA-positive cells infected with $^{b}:$} \\
\cline { 3 - 5 } & & Mock & NPC-KT virus & P3HR-1 virus \\
\hline 1 & - & $<0.1$ & 0.9 & 1.5 \\
1 & + & 0.3 & 11.0 & 1.0 \\
2 & - & $<0.1$ & 7.4 & 7.5 \\
2 & + & $<0.1$ & 95.0 & 7.5 \\
\hline
\end{tabular}

${ }^{a}$ Raji cells were mock infected or superinfected with unconcentrated NPC-KT or P3HR-1 virus (preparation 1) or virus concentrated 10-fold (preparation 2) and incubated in the presence or absence of DMSO (1\%).

${ }^{b}$ EA-positive cells were determined $48 \mathrm{~h}$ after infection.

cells were washed, they were lysed in $0.5 \mathrm{ml}$ of $50 \mathrm{mM}$ Tris ( $\mathrm{pH} 7.4)-5 \mathrm{mM}$ EDTA-150 mM NaCl-0.02\% sodium azide$0.25 \mathrm{mM}$ dithiothreitol-5 $\mu \mathrm{g}$ of phenylmethylsulfonyl fluoride per $\mathrm{ml}-0.5 \%$ Nonidet $\mathrm{P}-40$ and incubated at $4^{\circ} \mathrm{C}$ for 30 min. The mixtures were centrifuged at $30,000 \mathrm{rpm}$ in a $\mathrm{Ti}$ rotor (type 50; Beckman) for $1 \mathrm{~h}$. To the supernatant fluids 2 $\mu l$ of serum from patients with NPC (EA antibody titer, 1: 160 ; VCA 1:640) was added and incubated overnight at $4^{\circ} \mathrm{C}$. The antibody complexes were precipitated with protein A-coupled Sepharose CL-4B (Pharmacia, Inc., Piscataway, N.J.). The precipitate was washed 4 times with lysing buffer and subjected to sodium dodecyl sulfate-polyacrylamide gel electrophoresis. The gel was processed for fluorography with Amplify (Amersham Corp., Arlington Heights, Ill.).

Equilibrium density centrifugation. Raji cells $\left(1.0 \times 10^{5}\right)$ that were mock infected or superinfected with NPC-KT virus were incubated in the presence or absence of DMSO. At $6 \mathrm{~h}$ postinfection $20 \mu \mathrm{Ci}$ of $\left[{ }^{3} \mathrm{H}\right]$ thymidine was added, and incubation was continued until $24 \mathrm{~h}$ after infection. Both superinfected and mock-infected Raji cells were harvested; washed twice with phosphate-buffered saline by centrifuga-

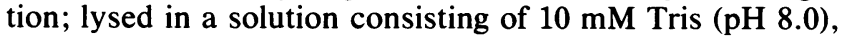
$0.5 \%$ sarcosyl, $1 \mathrm{mM}$ EDTA, $100 \mathrm{mM} \mathrm{NaCl}$, and $100 \mu \mathrm{g}$ of proteinase $\mathrm{K}$ per $\mathrm{ml}$; and analyzed by $\mathrm{CsCl}$ equilibrium density centrifugation at $40,000 \mathrm{rpm}$ at $20^{\circ} \mathrm{C}$ for $14 \mathrm{~h}$ in a rotor (TV-850; Ivan Sorvall, Inc., Norwalk, Conn.).

EBV DNA synthesized in superinfected cells. Raji cells $(5 \times$ $10^{6}$ ) were mock infected or superinfected with NPC-KT virus. After $90 \mathrm{~min}$ of adsorption at $37^{\circ} \mathrm{C}$, cells were washed 4 times with medium by centrifugation and incubated at $37^{\circ} \mathrm{C}$. After $24 \mathrm{~h}$ of incubation, cells were harvested and washed 4 times with phosphate-buffered saline solution. High-molecular-weight DNAs were extracted with phenol. Southern blots were prepared with EcoRI- or BamHI-digested DNA and hybridized to recombinant EBV DNA probes labeled with ${ }^{32} \mathrm{P}$ by nick translation $(22)$ or ${ }^{32} \mathrm{P}$ labeled RNA probes generated by SP6 polymerase. The viral right- and left-terminal fragments generated by $B a m \mathrm{HI}$ digestion were identified with a 1.9-kilobase (kb) Xhol fragment and the EcoRI-I portion of BamHI NJhet, as described previously (17).

\section{RESULTS}

Effect of DMSO on EA induction by EBV. Raji cells were superinfected with two preparations each of NPC-KT virus and HR-1 virus from unconcentrated cell culture supernatant fluids (preparation 1) or cell culture fluids that were concentrated 10-fold (preparation 2). When Raji cells were cultured in the presence of DMSO, EA induction was enhanced more

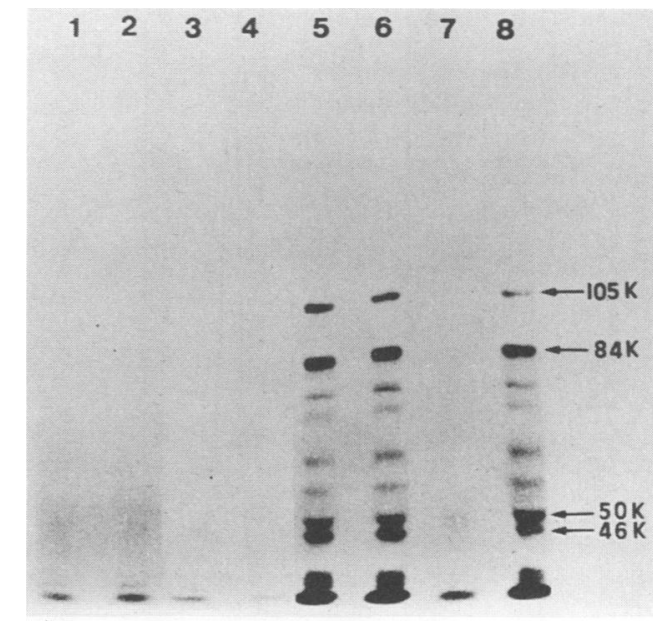

FIG. 1. Analysis by sodium dodecyl sulfate-polyacrylamide gel electrophoresis of EBV EA induction by NPC-KT and P3HR-1 viruses in the presence and absence of DMSO. Lanes: 1 , mockinfected Raji cells without DMSO; 2, mock-infected Raji cells with DMSO; 3, Raji cells superinfected with P3HR-1 virus $\left(3.7 \times 10^{4}\right.$ EAIU) without DMSO; 4, Raji cells superinfected with P3HR-1 virus $\left(3.7 \times 10^{4}\right.$ EAIU) with DMSO; 5, Raji cells superinfected with P3HR-1 virus $\left(4.8 \times 10^{5}\right.$ EAIU) without DMSO; 6, Raji cells superinfected with P3HR-1 virus $\left(4.8 \times 10^{5}\right.$ EAIU) with DMSO; 7 , Raji cells superinfected with NPC-KT virus $\left(3.8 \times 10^{4}\right.$ EAIU) without DMSO; 8, Raji cells superinfected with NPC-KT virus (3.8 $\times 10^{4}$ EAIU) with DMSO. Molecular weight markers ( $\mathrm{K}$ indicates thousands) were ${ }^{14} \mathrm{C}$-methylated carbonic anhydrase $(30,000),{ }^{14} \mathrm{C}$ methylated ovalbumin $(46,000),{ }^{14} \mathrm{C}$-methylated bovine serum albumin $(69,000),{ }^{14} \mathrm{C}$-methylated phosphorylase $b(92,500)$.

than 10-fold (Table 1). However, EA induction by HR-1 virus was unaffected or even inhibited by the drug. Exposure to DMSO for the first $8 \mathrm{~h}$ after superinfection enhanced EA induction to the maximum level. In the presence of DMSO, EA induction by NPC-KT virus was directly proportional to the dilution of the infecting virus (data not shown).

Induction of EA by NPC-KT and HR-1. Identification and comparison of the viral proteins induced after superinfection with HR-1 and NPC-KT virus were accomplished by pulselabeling with $\left[{ }^{35} \mathrm{~S}\right]$ methionine for $10 \mathrm{~h}$, precipitation with serum from patients with NPC, and sodium dodecyl sulfatepolyacrylamide gel electrophoresis. Raji cells superinfected with $3.7 \times 10^{4}$ EA-inducing units (EAIU) of P3HR-1 virus, which induced EA in $7.5 \%$ of the cells, did not synthesize detectable amounts of EA polypeptides, despite the presence of DMSO (Fig. 1, lanes 3 and 4). In Raji cells superinfected with $3.7 \times 10^{4}$ EAIU of NPC-KT virus incubated without DMSO, the frequency of EA-expressing cells was $7.4 \%$, and again, EA polypeptides were not detected (Fig. 1, lane 7). However, more than $95 \%$ of cells superinfected with the same concentration of virus and incubated in the presence of DMSO synthesized EA and EBV-specific EA polypeptides (Fig. 1, lane 8). The most abundant EA components induced were the 105-, 84-, 50-, and 46-kilodalton proteins. In contrast, DMSO had no effect with HR-1 virus. Superinfection with $4.8 \times 10^{5}$ EAIU of HR-1 virus induced EA polypeptide synthesis in 88 and $95 \%$ of Raji cells without and with DMSO respectively (Fig. 1, lanes 5 and 6, respectively). The same pattern of protein synthesis was detected with EBV-positive antisera in Raji cells infected with NPC-KT or HR-1. These data indicate that NPC-KT and HR-1 have similar effects on EBV protein synthesis. 


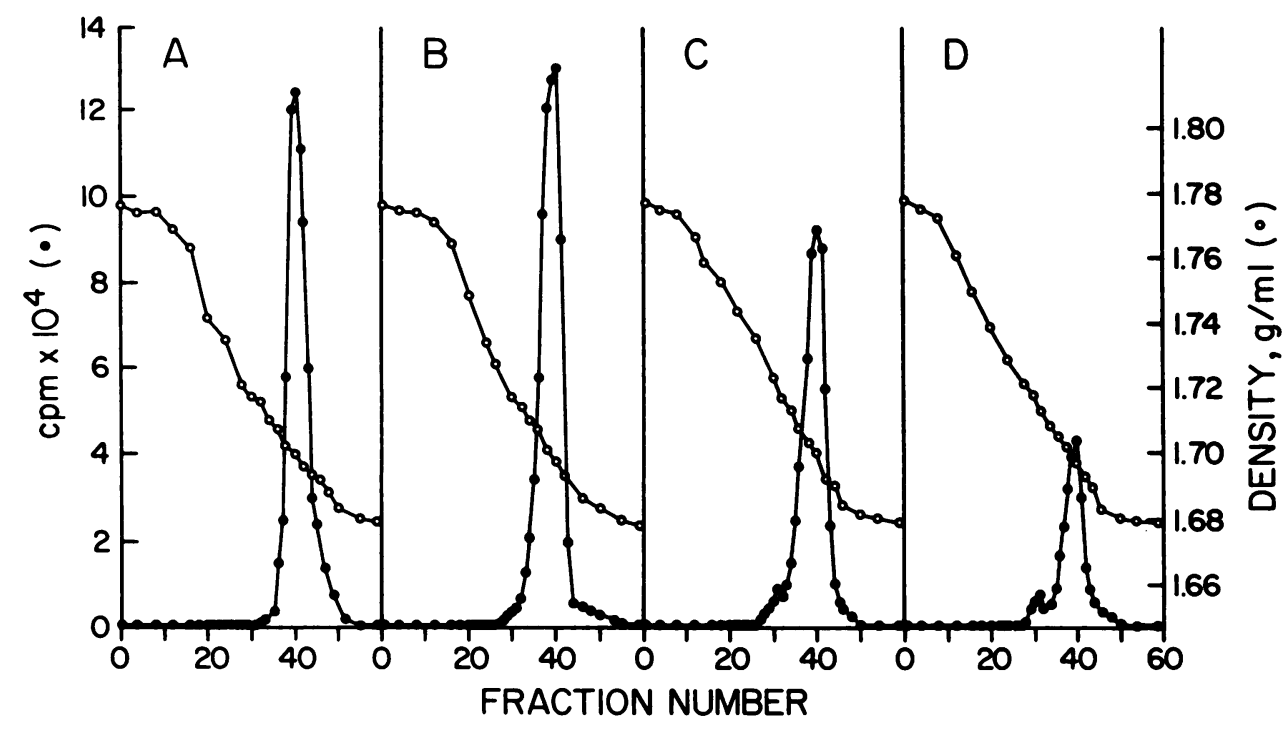

FIG. 2. Analysis of DNA synthesized in Raji cells superinfected with NPC-KT virus by $\mathrm{CsCl}$ equilibrium density centrifugation. (A and B) Mock-infected Raji cells with (A) and without (B) DMSO. (C and D) Raji cells superinfected with NPC-KT virus with (C) and without (D) DMSO.

Viral DNA synthesis. Other laboratory strains of EBV, i.e., subclones of the HR-1 cell line which have lost defective molecules and B95-8, can induce early antigen synthesis in Raji cells if a high multiplicity of infection is attained (12). In contrast to superinfection with parental HR-1, in which the defective molecules are preferentially synthesized $(2,13)$, viral DNA synthesis was not induced. In Raji cells superinfected with NPC-KT virus, newly synthesized DNA was analyzed after pulse-labeling between 6 and $24 \mathrm{~h}$ postinfection (Fig. 2). The percentage of EA-positive cells after superinfection with and without DMSO was 15 and $>95 \%$, respectively. In the presence of DMSO, cellular DNA synthesis was inhibited by approximately $70 \%$, and a distinct peak of viral DNA was detected (Fig. 2D).

The viral DNA synthesized after superinfection was analyzed after restriction enzyme digestion. Both the NPC-KT and Raji EBV genomes have several unique restriction enzyme polymorphisms which distinguish the two genomes (27). Total intracellular DNA was prepared from DMSOtreated Raji cells at $24 \mathrm{~h}$ after infection with NPC-KT virus and from mock-infected cells. Duplicate preparations with 1 $\mu \mathrm{g}$ of each intracellular DNA and $10 \mathrm{ng}$ of NPC-KT virion DNA digested with EcoRI and BamHI were prepared. Ethidium bromide staining of these gels (Fig. 3A) indicated that there were equal amounts of intracellular DNA per lane. After transfer to nitrocellulose, the blots were hybridized with ${ }^{32}$ P-labeled EBV restriction enzyme fragments which would identify fragments unique to the NPC-KT and Raji genomes (Fig. 3B). Raji EBV DNA has a 1.4-kb deletion of part of the BamHI E and Z fragments and all of the $d$ and $e 3$ fragments, resulting in a fused $E-Z$ fragment. Hybridization with Bam HI-Z to superinfected or mock-infected Raji DNA identified a significant increase in the $B a m H I ~ E-Z$ fragment of Raji cells, although the fragment was less abundant than the BamHI Z fragment of the NPC-KT genome (Fig. 3B). This hybridization was confirmed by hybridization with BamHI-E, which identified in EcoRI digestions an increase of the EcoRI B fragment of Raji DNA and strong hybridization to the unique EcoRI $\mathrm{H}$ fragment of NPC-KT. This resulted from an additional EcoRI site in the sequences homologous to EcoRI-B. The increased intensity of hybrid- ization to Raji-specific fragments indicates that after superinfection with NPC-KT virus, there is amplification of the resident viral genome.

Amplification of the Raji genome was confirmed in hybridizations in which other Raji-specific fragments were identified. NPC-KT virus is missing the BamHI site between the BamHI T and X fragments, which produces an NPC-KTspecific fragment, BamHI-I. Hybridization with EcoRI-H did not allow detection of the Raji-specific BamHI T fragment in the DNA preparation from the mock-infected cell line. However, after superinfection the BamHI T fragment was detected, in addition to the NPC-KT I fragment (Fig. 3B).

Similarly, Raji DNA lost the BamHI site between BamHI $\mathrm{U}$ and $\mathrm{P}$, resulting in a fused $\mathrm{U}-\mathrm{P}$ fragment. By hybridization with BamHI-U, the U fragment of NPC-KT in the intracellular DNA from the superinfected Raji cells and an increased amount of the Raji-specific U-P fragment were detected, when compared with DNA from the mock-infected Raji cells.

In order to determine the magnitude of the increase in the resident Raji EBV genome and to determine whether the superinfecting NPC-KT viral genome was also replicated, DNA was prepared from Raji cells after superinfection before incubation at $37^{\circ} \mathrm{C}$ and after incubation for $24 \mathrm{~h}$ (Fig. 4 , lanes 2 and 3, respectively). A gel containing $1 \mu \mathrm{g}$ of these DNAs, 1 and $3 \mu \mathrm{g}$ of DNA from mock-infected Raji cells incubated with DMSO (Fig. 4, lanes 4 and 5, respectively), and $1 \mu \mathrm{g}$ of Raji DNA mock-infected in the absence of DMSO (Fig. 4, lane 6) was transferred to nitrocellulose. After hybridization to Bam $\mathrm{HI}-\mathrm{U}$, comparison of the relative intensity of hybridization, determined by densitometric scanning, indicated that if the number of EBV genomes in Raji cells is assumed to be 60 , the multiplicity of superinfection was approximately 160 copies per cell. Superinfection with a multiplicity of infection greater than 3,000 copies per cell of strains of EBV other than HR-1 can induce EA synthesis (12). After incubation for $24 \mathrm{~h}$, the intensity of the NPC-KT-specific BamHI U fragment increased approximately fivefold, indicating that the superinfecting NPC-KT genome was also amplified. Densitometric scanning and 
A

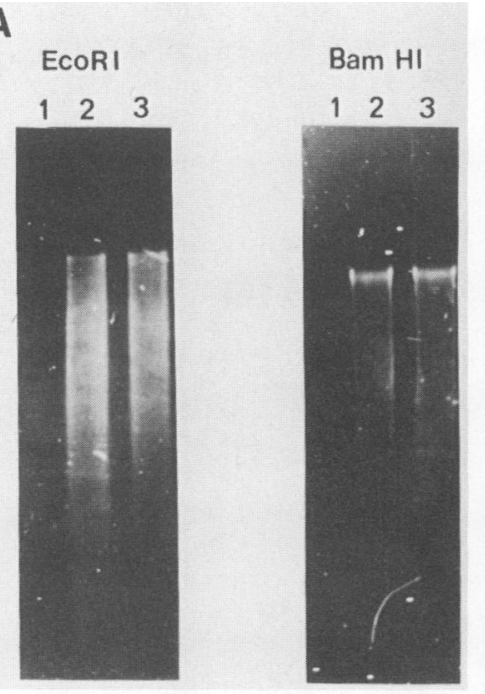

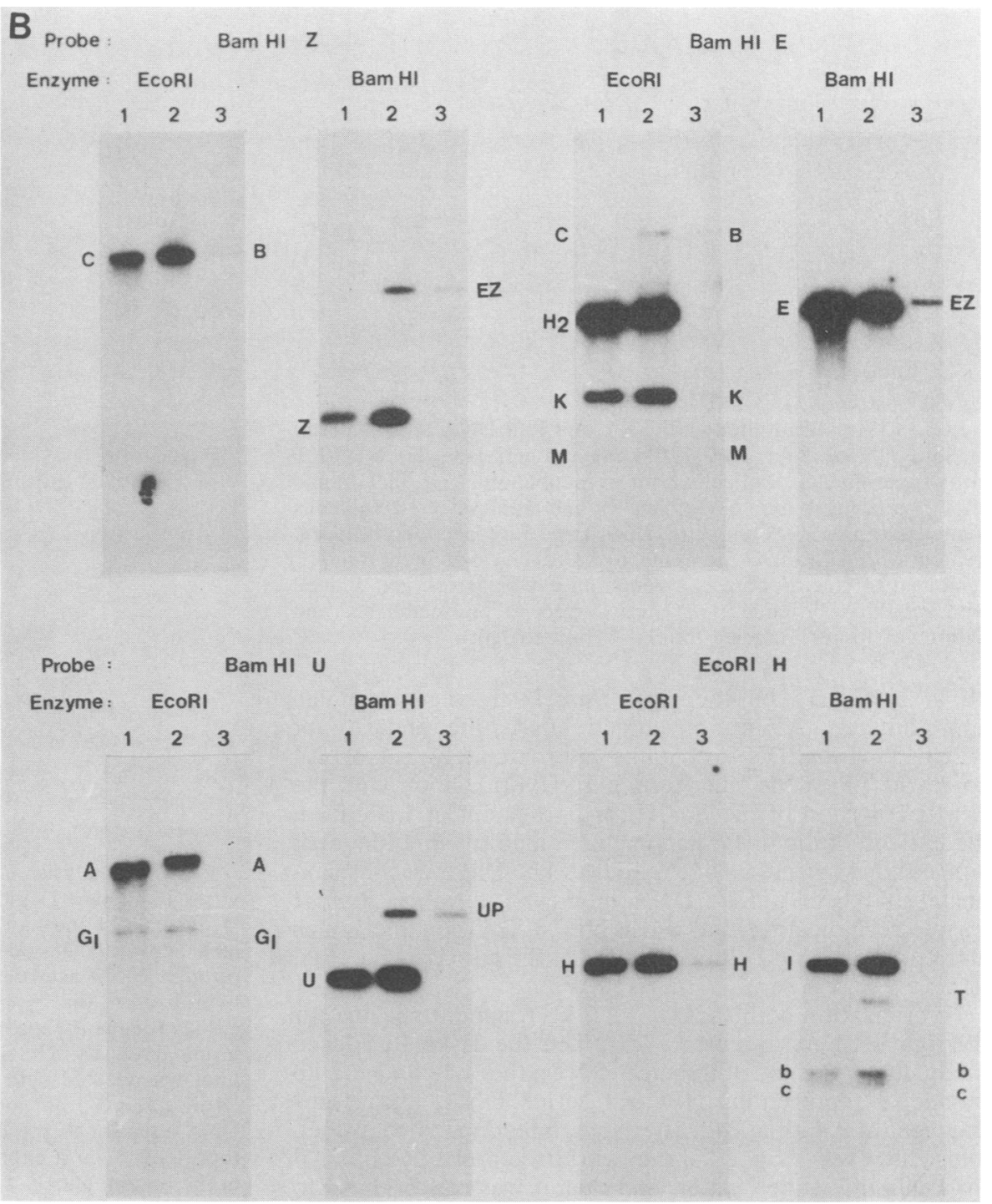

FIG. 3. Identification of amplified Raji DNA. DNA from NPC-KT virus (10 ng; lane 1), Raji cells superinfected with NPC-KT virus (1 $\mu$ g; lane 2), and mock-infected NPC-KT (1 $\mu \mathrm{g}$; lane 3$)$ in the presence of DMSO were digested with either EcoRI or BamHI (A) and hybridized to ${ }^{32} \mathrm{P}$-labeled BamHI E, Z, and $\mathrm{U}$ fragments and the EcoRI $\mathrm{H}$ fragment (B).

determination of the peak areas indicated a value of 0.97 $\mathrm{mm}^{2}$ for the Raji-specific U-P band in the lane containing 1 $\mu \mathrm{g}$ of mock-infected Raji DNA, $3.03 \mathrm{~mm}^{2}$ in the lane containing $3 \mu \mathrm{g}$ of mock-infected Raji DNA, and $3.43 \mathrm{~mm}^{2}$ for the lane containing $1 \mu \mathrm{g}$ of superinfected Raji DNA (Fig. 4). These data reveal that there is a good correlation for the amount of DNA loaded per lane, as determined by optical density, ethidium bromide staining, and hybridization. The data also indicate that there is at least a threefold increase in the resident Raji genome. These data suggest that superinfection with NPC-KT virus not only induces the synthesis of early antigen in Raji cells but also induces viral DNA synthesis composed of both the endogenous and superinfecting viral genomes.

Circularization of the superinfecting EBV genome. The terminal restriction enzyme fragments of EBV are heterogeneous in molecular weight because of various numbers of copies of the 500-base-pair direct tandem repeat unit (TR), which is present at both ends of the linear genome $(5,11)$.
After infection, the EBV genome circularizes via the terminal repeats. Fused terminal fragments can be identified in intracellular DNA by hybridization to probes from both ends of the linear genome (17). In Raji DNA a single fused terminal fragment of approximately $21 \mathrm{~kb}$ was detected, which indicates that the multiple episomal copies of EBV in Raji contain a constant number of TRs. The particularly large size of the Raji BamHI fused fragment was due to the loss in Raji DNA of the rightmost BamHI site present in most EBV strains. The very large BamHI fragment of the resident Raji genome should be readily distinguished from fused fragments produced from the superinfecting NPC-KT strain which retains the $B a m H I$ restriction site. The terminal restriction enzyme fragments of NPC-KT are much less heterogeneous than those detected in laboratory strains of EBV, such as B95-8, W91, or AG876 (7).

Hybridization with a 1.9-kb XhoI fragment from the unique DNA adjacent to the TR at the right terminus identified two predominant BamHI fragments of 4.7 and 4.2 


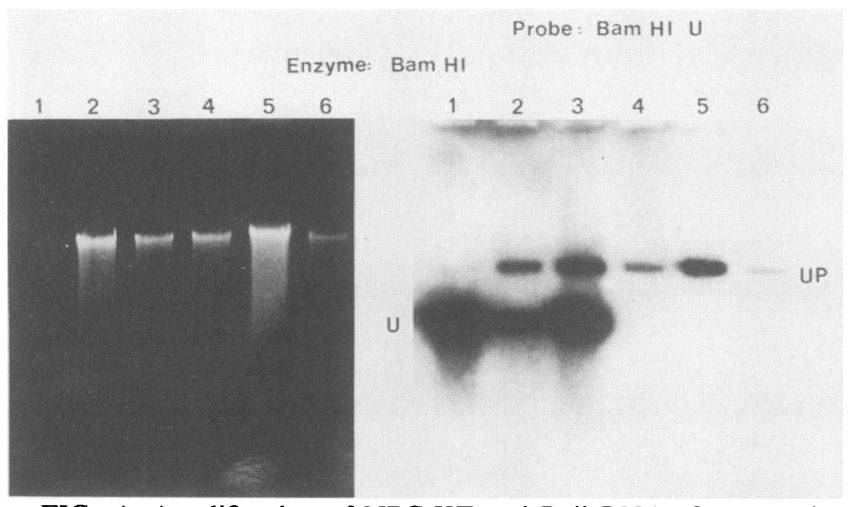

FIG. 4. Amplification of NPC-KT and Raji DNA after superinfection. DNAs from NPC-KT virus (10 ng; lane 1), NPC-KT virus-superinfected Raji cells prior to incubation ( $1 \mu \mathrm{g}$; lane 2$)$ and after $24 \mathrm{~h}$ of incubation ( $1 \mu \mathrm{g}$; lane 3), and mock-infected Raji cells treated with DMSO ( 1 and $3 \mu \mathrm{g}$; lanes 4 and 5, respectively) and not treated with DMSO (1 $\mu \mathrm{g}$; lane 6) were digested with BamHI, subjected to electrophoresis through an $0.8 \%$ agarose gel, stained with ethidium bromide (left), transferred to nitrocellulose, and hybridized to a ${ }^{32}$ P-labeled BamHI-U probe (right).

$\mathrm{kb}$ in NPC-KT. As the right BamHI fragment contains approximately $3.5 \mathrm{~kb}$ of unique DNA, the majority of NPC-KT virion DNA contains approximately 1.4 or 2.4 copies of TR at the right terminus. Hybridization with the EcoRI-I portion of the BamHI N-J fragment of EBV from the left end of the linear genome identified two predominant left-terminal fragments of 5.2 and $4.7 \mathrm{~kb}$. There was approximately $4 \mathrm{~kb}$ of unique DNA in the left-terminal BamHI fragment, indicating that most NPC-KT virion molecules also contain 1.4 or 2.4 copies of TR at the left terminus (Fig. 5).

Hybridization with the XhoI 1.9-kb fragment specific for the right-terminal fragments identified the 21-kb Raji fused fragment in the mock-infected DNA, the $4.2-$ and $4.7-\mathrm{kb}$ fragments representing NPC-KT virion DNA, and a new fragment of $9.4 \mathrm{~kb}$ at $24 \mathrm{~h}$ after superinfection. The nitrocellulose filter was stripped of the hybridized probe by boiling it for $1 \mathrm{~min}$ in distilled water, and then it was rehybridized to EcoRI-I. This probe also identified the $21-\mathrm{kb}$ fused Raji fragment representing the Raji EBV episome, the 5.2- and 4.7-kb left-terminal fragments of NPC-KT virion DNA, and the new 9.4-kb fragment.

The hybridization of probes from both the right and left ends of the linear genome to the 9.4-kb fragment suggests that NPC-KT virus circularizes or forms concatamers after superinfection. Densitometric scanning and comparison of the relative intensity of hybridization indicated that greater than $80 \%$ of the NPC-KT genome circularizes by $24 \mathrm{~h}$ postinfection or is present in a replicative intermediate which contains fused terminal fragments. Although fused terminal fragments with three or five copies of TR would not be well resolved, the predominant fused terminal fragment of $9.4 \mathrm{~kb}$ would have approximately four copies of TR.

\section{DISCUSSION}

The NPC-KT virus provides the first opportunity to characterize the molecular biologic properties of an epithelial cell-derived strain of EBV. In this study, superinfection by NPC-KT virus and activation of a latent viral infection were characterized further.

The data presented here reveal that the same polypeptides are induced by HR-1 or NPC-KT virus and that NPC-KT

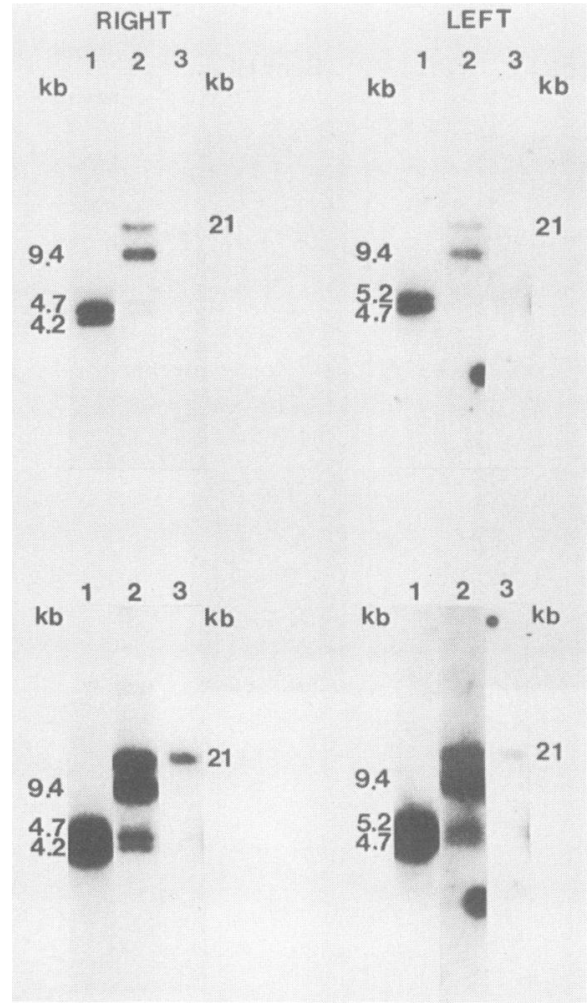

FIG. 5. Analysis of viral genomic termini. DNAs from NPC-KT virus (10 ng; lane 1) and Raji cells superinfected with NPC-KT virus $(1 \mu \mathrm{g}$; lane 2$)$ and mock infected in the presence of DMSO $(1 \mu \mathrm{g}$; lane 3) were digested with $B a m \mathrm{HI}$, subjected to electrophoresis through a $0.6 \%$ agarose gel, transferred to a nitrocellulose filter, and hybridized to the ${ }^{32} \mathrm{P}$-labeled SP6 RNA transcribed from the XhoI 1.9-kb fragment representing unique DNA adjacent to the rightterminal repeats (RIGHT). After autoradiography, the nitrocellulose filter was treated with boiling water and hybridized with the ${ }^{32} \mathrm{P}$ labeled EcoRI-I portion of BamHI NJhet which represents unique DNA adjacent to the left-terminal repeats (LEFT). The top panel represents a short exposure of the same autoradiograms presented in the bottom panel.

virus also has the capacity to induce viral DNA synthesis. The data also indicate that defective molecules are not generated during the process of superinfection and therefore are not necessary for superinfection by NPC-KT virus. In addition, it is evident that both the endogenous and superinfecting EBV genomes are amplified during superinfection. This is suggested by the enhanced detection of restriction enzyme fragments unique to each genome and by the detection of a unique fused terminal fragment representing NPCKT DNA.

The fused terminal fragment that was generated after superinfection provides additional information on the events early after superinfection. It suggests that the NPC-KT virus efficiently circularizes or polymerizes after superinfection, so that by $24 \mathrm{~h}$ the fused terminal fragment represents the majority of the superinfecting genome. This is in marked contrast to superinfection by B95-8, which inefficiently forms fused terminal fragments after superinfection $(H$. Sato and N. Raab-Traub, unpublished data). Superinfection of a latently infected cell line with B95-8 revealed that at $48 \mathrm{~h}$ postinfection approximately $20 \%$ of the B95-8 molecules apparently circularized and that, as expected, the fused terminal fragments were heterogeneous, reflecting various 
numbers of TR at each terminus (21). Perhaps the inefficiency of B95-8 to superinfect Raji cells is related to an inability to circularize efficiently or form concatamers.

Although NPC-KT virion DNA contains two predominant right-terminal fragments of 4.2 and $4.7 \mathrm{~kb}$, representing approximately 1.4 and 2.4 copies of TR, and two predominant left-terminal fragments of 4.7 and $5.2 \mathrm{~kb}$, containing 1.4 and 2.4 copies of TR, a predominant fused terminal fragment of $9.4 \mathrm{~kb}$ was formed after superinfection. If the number of TR on the linear molecules were randomly distributed, it would be expected that fused fragments of $8.9,9.4$, and 9.9 $\mathrm{kb}$ would be produced. The detection of a predominant 9.4-kb fragment suggests that the majority of molecules which have 2.4 copies of TR at the right terminus have 1.4 copies of TR at the left terminus, molecules with 1.4 copies of TR at the right terminus have 2.4 copies of TR at the left terminus, and the termini are ligated intramolecularly after superinfection. The implication is that the replicative intermediate which is the template for the generation of linear fragments has a constant number of TRs (approximately four) and that the replicative intermediate is cleaved at some site within TR to generate linear molecules whose total number of TRs at both termini is constant and equal to those in the replicative intermediate. In NPC-KT cells, a replicative intermediate with four copies of TR is selectively amplified after 5-iodo-2'-deoxyuridine induction (unpublished data). The detection of a predominant fused fragment after superinfection implies that in NPC-KT cells, the linear fragments are produced by cleavage of amplified episomal DNA containing four copies of TR. The possibility that episomal DNA is a replicative intermediate which is amplified by the viral DNA polymerase has also been suggested by data which showed that acyclovir or phosphonoacetic acid treatment not only eliminates the generation of linear viral DNA but also decreases the covalently closed episomal DNA copy number (24).

In this study the efficiency of superinfection by NPC-KT was significantly enhanced by treatment with DMSO, which had no effect on EBV expression in mock-infected Raji cells or on the efficiency of superinfection by HR-1 virus. DMSO has been shown to alter cellular expression and to induce differentiation of erythroleukemic cells, to enhance replication of cytomegalovirus, and possibly, to affect the degree of EBV viral replication in cell lines transformed in the presence of DMSO (29-31). It has been suggested previously (25, 26) that EBV replication occurs in the oropharyngeal epithelial cells as they differentiate and are sloughed into the oropharynx. Therefore, DMSO enhancement of superinfection by NPC-KT may reflect its effects on cellular expression, although it is unclear why it would not also enhance superinfection by HR-1. NPC-KT is distinct from HR-1 virus in that its membrane envelope is derived from epithelial cells, not lymphoid cells. Perhaps NPC-KT virus differs in viral or cellular membrane components and the effect of DMSO is more pronounced or essential for the epithelial cell-derived NPC-KT.

\section{ACKNOWLEDGMENTS}

This study was supported by Public Health Service grants CA 19014 and CA 32979 from the National Cancer Institute.

We thank Teri L. Lanier for excellent secretarial assistance.

\section{LITERATURE CITED}

1. Bornkamm, G. W., J. Hudewentz, U. K. Freese, and U. Zimber. 1982. Deletion of the nontransforming Epstein-Barr virus strain P3HR-1 causes fusion of the large internal repeat to the DSL region. J. Virol. 43:952-968.

2. Cho, M. S., G. W. Bornkamm, and H. zur Hausen. 1984. Structure of defective DNA molecules in Epstein-Barr virus preparations from P3HR-1 cells. J. Virol. 51:199-207.

3. Countryman, J., and G. Miller. 1985. Activation of expression of latent Epstein-Barr herpesvirus after gene transfer with a small cloned subfragment of heterogeneous DNA. Proc. Natl. Acad. Sci. USA 82:4085-4089.

4. Delius, H., and G. W. Bornkamm. 1978. Heterogeneity of Epstein-Barr virus. III. Comparison of a transforming and a nontransforming virus by partial denaturation mapping of their DNAs. J. Virol. 27:81-89.

5. Given, D., D. Yee, K. Griem, and E. Kieff. 1979. DNA of Epstein-Barr virus. V. Direct repeats at the ends of EpsteinBarr virus DNA. J. Virol. 30:852-862.

6. Hayward, S. D., S. G. Lazarowitz, and G. S. Hayward. 1982. Organization of the Epstein-Barr virus DNA molecule. II. Fine mapping of the boundaries of the internal repeat cluster of B95-8 and identification of additional small tandem repeats adjacent to the HR-1 deletion. J. Virol. 43:201-212.

7. Heller, M., T. Dambaugh, and E. Kieff. 1981. Epstein-Barr virus DNA. IX. Variations among viral DNAs from producer and nonproducer infected cells. J. Virol. 38:632-648.

8. Hinuma, Y., M. Konn, J. Yamaguchi, D. J. Wudarski, J. R. Blakeslee, and J. T. Grace. 1967. Immunofluorescence and herpes-type particles in the P3HR-1 Burkitt lymphoma cell line. J. Virol. 1:1045-1051.

9. Jones, M. D., L. Foster, T. Sheedy, and B. Griffin. 1984. The EB virus genome in Daudi Burkitt's lymphoma cells has a deletion similar to that observed in a nontransforming strain (P3HR-1) of that virus. EMBO J. 3:813-821.

10. King, W., T. Dambaugh, M. Heller, J. Dowling, and E. Kieff. 1982. Epstein-Barr virus DNA. XII. A variable region of the EBV genome is included in the P3HR-1 deletion. J. Virol. 43: 979-986.

11. Kintner, C. R., and B. Sugden. 1979. The structure of the termini of the DNA of Epstein-Barr virus. Cell. 17:661-671.

12. Lin, J. C., and N. Raab-Traub. 1987. Two strains of EpsteinBarr virus (B95-8 and a P3HR-1 subclone) that lack defective genomes induce early antigen and cause abortive infection of Raji cells. J. Virol. 61:1985-1991.

13. Miller, G., L. Heston, and J. Countryman. 1985. P3HR-1 Epstein-Barr virus with heterogeneous DNA is an independent replicon maintained by cell-to-cell spread. J. Virol. 54:45-52.

14. Miller, G., M. Rabson, and L. Heston. 1984. Epstein-Barr virus with heterogeneous DNA disrupts latency. J. Virol. 50:174-182.

15. Miller, G., J. Robinson, L. Heston, and M. Lipman. 1974. Differences between laboratory strains of Epstein-Barr virus based on immortalization, abortive infection, and interference. Proc. Natl. Acad. Sci. USA 71:4006-4010.

16. Raab-Traub, N., T. Dambaugh, and E. Kieff. 1980. DNA of Epstein-Barr virus. VIII. B95-8, the previous prototype, is an unusual deletion derivative. Cell 22:257-267.

17. Raab-Traub, N., and K. Flynn. 1986. The structure of the termini of the Epstein-Barr virus as a marker of clonal cellular proliferation. Cell 47:883-889.

18. Raab-Traub, N., R. Pritchett, and E. Kieff. 1978. DNA of Epstein-Barr virus. III. Identification of restriction enzyme fragments that contain DNA sequences which differ among strains of Epstein-Barr virus. J. Virol. 27:388-398.

19. Rabson, M., L. Gradoville, L. Heston, and G. Miller. 1982. Nonimmortalizing P3J-HR-1 Epstein-Barr virus: a deletion mutant of its transforming parent, Jijoye. J. Virol. 44:834-844.

20. Rabson, M., L. Heston, and G. Miller. 1983. Identification of a rare Epstein-Barr virus variant that enhances early antigen expression in Raji cells. Proc. Natl. Acad. Sci. USA 80:27622766.

21. Reisman, D., and B. Sugden. 1984. An EBNA-negative, EBVgenome-positive human lymphoblast cell line in which superinfecting EBV DNA is not maintained. Virology 137:113-126.

22. Rigby, P. W. J., M. Dieckmann, C. Rhodes, and P. Berg. 1977. Labeling deoxyribonucleic acid to high specific activity in vitro by nick translation with DNA polymerase. J. Mol. Biol. 113: 
237-251.

23. Sato, H., T. Takimoto, H. Ogura, M. Hatano, and R. Glaser. 1986. Heterogeneity of Epstein-Barr virus derived from a nasopharyngeal carcinoma which has transforming and lytic properties. J. Natl. Cancer Inst. 76:1019-1024.

24. Shaw, J. 1984. The circular form of Epstein-Barr virus DNA is amplified by the virus-associated DNA polymerase. J. Virol. 53: 1012-1015.

25. Sixbey, J., J. G. Nedrud, N. Raab-Traub, R. A. Hanes, and J. S. Pagano. 1984. Detection of Epstein-Barr virus DNA and RNA in human pharyngeal epithelial cells. N. Engl. J. Med. 310:12251230.

26. Sixbey, J., E. Vesterinen, J. G. Nedrud, N. Raab-Traub, L. A. Walton, and J. S. Pagano. 1983. EBV replication in human epithelial cells infected in vitro. Nature (London) 306:480-483.

27. Skare, J., J. Farley, J. L. Strominger, K. Fresen, M. S. Cho, and H. zur Hausen. 1985. Transformation by Epstein-Barr virus requires DNA sequences in the region of Bam HI fragments $Y$ and H. J. Virol. 55:286-297.

28. Takimoto, T., M. Kamide, and R. Umeda. 1984. Establishment of Epstein-Barr virus (EBV)-associated nuclear antigen (EBNA)-positive nasopharyngeal carcinoma hybrid cell line (NPC-KT). Arch. Otorhinolaryngol. 239:87-92.

29. Takimoto, T., H. Ogura, H. Sato, R. Umeda, and M. Hatano. 1985. Isolation of transforming and early antigen-inducing Epstein-Barr virus from nasopharyngeal carcinoma hybrid cells (NPT-KT). J. Natl. Cancer Inst. 74:57-59.

30. Tanaka, J., S. Kamiya, T. Ogura, H. Sato, H. Ogura, and M. Hatano. 1985. Effect of dimethyl sulfoxide on interaction of human cytomegalovirus with host cell: conversion of a nonproductive state of cell to a productive state for virus replication. Virology 146:165-176.

31. Wilson, G. 1983. Transformation in the presence of dimethyl sulfoxide facilitates recovery of Epstein-Barr virus. Intervirology 19:56-60. 